\title{
Conserving and Sustaining Culture through Sarawak Traditional Malay Woman Headscarves
}

\author{
Awang Rozaimie ${ }^{*}$, Rashidah Bolhassan ${ }^{2}$, Regina Garai Abdullah ${ }^{3}$ and \\ Aiza Johari ${ }^{4}$ \\ ${ }^{1 \& 4}$ Universiti Teknologi MARA, Cawangan Sarawak, MALAYSIA \\ ${ }^{2}$ Pustaka Negeri Sarawak, Sarawak, MALAYSIA \\ ${ }^{3}$ Universiti Malaysia Sarawak, Sarawak, MALAYSIA \\ 1awgrozaimie@uitm.edu.my; ${ }^{2}$ rashidahb@sarawak.gov.my; \\ 3argarai@unimas.my; ${ }^{4}$ aiza@uitm.edu.my
}

Received: 2 February 2020

Accepted: 30 April 2020

Published: 30 June 2020

\begin{abstract}
The traditionally Sarawak Malay woman headscarf is known as Tudong Selayah Keringkam. It is a hand-made identical embroidery headscarf, produced with articulate skills, creativity, and imagination and worn as a social identity among the Malay women in Sarawak. This paper argues that the Selayah and the Keringkam are two different pieces of headscarves artwork. This paper also foresees the reasons behind the depletion of interest and skills of producing this artifact among the younger generation, to a large extent, making the cultural sustainability of the traditional headscarves in Sarawak to become less significant. Hence, the objectives of this paper are to explore the distinction between Selayah and Keringkam. In this transcendental phenomenological paper, the 'framing approach' is used in the in-depth interviews conducted with Selayah Keringkam weavers and Malay elders. This paper apparently has found the little provision to the distinction between Selayah and Keringkam. However, there are five elements posited which have contributed to the depletion of interest among the young generation in the production of Selayah Keringkam. Those elements are labelled as Price, Realism, Technology, Proficient and Insight. Nonetheless, this paper is significant in highlighting the Selayah Keringkam as one of the key material cultures in sustaining Sarawak Malay heritage. Preserving and sustaining the social identity is crucial which potentially becomes central
\end{abstract}


to the tourism products and commercially plated onto the international arena of fashion, art, and design.

Keywords: headscarf, social identity, ethnicity, heritage, tangible culture, conservation, sustainability

\section{INTRODUCTION}

The Malay women in Malaysia are synonymous with Baju Kurung, Kebaya, Kebarung and headscarf or hijab. Wearing hijab professes an obligation to Islam while wearing a headscarf is considered giving respect or fashion to others. Headscarves among the women in Sarawak are sufficiently adapted to show religious respect as well as become a part of the cultural material. Respect is an essential service to others. In the past, refined design and embroidery on the traditional clothing, especially the headscarves, stood out as a stylish appearance of the home-made artwork (Abang Josmani, Kibat, Halamy \& Valerie, 2012). These traditional crafts have gradually disappeared due to modernisation and simplification of today's living. The scarcity of resources and complicated process of making such crafts led to the depletion of knowledge in the making of the Selayah Keringkam, which used to be part of Sarawak Malay women's identity. The Selayah Keringkam is one of the unique traditional crafts among Malay women in Sarawak. It is codified as part of the material culture of their everyday life. However, there is a lack of documented record to show its origin. Additionally, public appearances of Selayah Keringkam in printed form can be found in the writing of Ranee Margaret Brooke, the Second Rajah's ${ }^{1}$ lady. In her book 'My Life in Sarawak' (Brooke, 1913), a picture of Ranee wearing a complete set of Sarawak Malay women costume was included (see Figure 1).

\footnotetext{
${ }^{1}$ The second White Rajah of Sarawak, Charles Anthony Johnson Brooke (also known as Charles Brooke), head of state of Sarawak $3^{\text {rd }}$ August $1868-17^{\text {th }}$ May 1917.
} 